\title{
Advocacy coalitions, REDD+, and forest governance in Papua New Guinea: how likely is transformational change?
}

\author{
$\underline{\text { Andrea Babon }}^{1,2}$, Daniel McIntyre $^{2}$, Gae Y. Gowae $^{3}$, Caleb Gallemore $^{2,4}$, Rachel Carmenta $^{2}, \underline{\text { Monica Di Gregorio }}^{2,5}$ and Maria $^{\text {Bacthe }}$ \\ Brockhaus $^{2}$
}

\begin{abstract}
Tropical forests in developing countries are increasingly being valued for their role in carbon sequestration. Such interest is reflected in the emergence of international initiatives for Reducing Emissions from Deforestation and Forest Degradation (REDD+). REDD+ requires addressing both tropical forests as complex social-ecological systems and the multiple sectors involved in tropical forest resources, which may necessitate transformational change away from business-as-usual approaches to forest governance. We studied the potential for REDD+ to mobilize an influential coalition of actors promoting transformational change in forest governance in Papua New Guinea (PNG), a leading proponent of REDD+ internationally. Combining policy network approaches with the advocacy coalition framework, we identified four advocacy coalitions in the REDD+ policy domain in PNG and estimated the influence of each coalition. We found the most influential advocacy coalition is promoting the status quo rather than governance reforms capable of reducing deforestations and forest degradation, leading us to suggest that business as usual is the dominant perspective in the REDD+ policy domain in PNG. This may explain why, despite the large amount of REDD+ rhetoric, there has been only modest change in formal policy or practice in PNG to date. However, we did find influential coalitions calling for transformational change. Although these are currently minority coalitions, we identified several pathways through which they could increase their power to realize transformational change
\end{abstract}

Key Words: advocacy coalition framework; advocacy coalitions; forest governance; Papua New Guinea; REDD+; transformational change

\section{INTRODUCTION}

The role of tropical forests in global climate change mitigation has received increasing international attention over the past decade (Fearnside 2000, Soares-Filho et al. 2010, Fearnside 2012). Proposals to reduce carbon emissions from deforestation and forest degradation and enhance forest carbon stocks (REDD+) have gained momentum in international climate change negotiations (Angelsen et al. 2009), and many developing countries are currently in the process of formulating national REDD+ policies and strategies (see, e.g., UN-REDD Programme 2009). Given that tropical forests in developing countries are complex social-ecological systems (Ostrom and Nagendra 2006, Gardner et al. 2013) embedded in multilevel social, ecological, and often highly political processes (Schmink and Wood 1992, Young et al. 2006, Korhonen-Kurki et al. 2012), it has been suggested that REDD+ will require transformational change in and beyond the forest sector that challenges business-as-usual approaches to the use and management of tropical forests (Brockhaus and Angelsen 2012).

Policy network theories suggest that, although politicians and state actors have final decision-making power, policy emerges from a network of interdependent state and nonstate actors (Laumann and Knoke 1987, Marsh and Rhodes 1992, Knoke et al. 1996). Within a particular policy domain, organizations must bargain with one another to secure policy outcomes (Marsh and Rhodes 1992) and may form advocacy coalitions based on shared beliefs to influence government policy and achieve common objectives (Weible 2005, Weible and Sabatier 2005, Ingold 2011).

In this article, we use policy network approaches to analyze the potential for REDD+ to mobilize influential coalitions of actors promoting transformational change within national forest policy domains. Following Brockhaus and Angelsen (2012:17), we defined transformational change as "a shift in discourse, attitudes, power relations, and deliberative policy and protest action that leads policy formulation and implementation away from business as usual policy approaches that directly or indirectly support deforestation and forest degradation."

In particular, we applied the Advocacy Coalition Framework (ACF; Sabatier and Weible 2007) to identify the presence and influence of coalitions of actors advocating for transformational change in forestry policy in Papua New Guinea (PNG). Using a mixed-methods approach that combines quantitative survey data with qualitative data from semistructured interviews and document reviews, we asked the following research questions: (1) Is there evidence of advocacy coalitions promoting transformational change in the REDD+ policy domain in PNG? (2) How influential are coalitions for transformational change?

\section{Forests and governance in PNG}

PNG's forests are globally significant. The island of New Guinea hosts the third largest tropical forest in the world (Shearman et al. 2008). PNG occupies the eastern half of New Guinea and, despite covering less than $1 \%$ of the world's land mass, the country supports more than $5 \%$ of the world's biodiversity, including many endemic species (Government of Papua New Guinea 2007, World Wildlife Fund, wwf.panda.org/what_we do/where we work/ new guinea forests/). However, PNG's forests are facing drivers of deforestation and forest degradation ranging from commercial logging to conversion to smallholder and large-scale agriculture. From 1972 to 2002, the estimated annual rate of deforestation and forest degradation in PNG was 1.41\% (Shearman et al. 2009).

The forestry sector in PNG is characterized by illegal and unsustainable commercial logging (Bun et al. 2004, Shearman et

${ }^{1}$ Charles Darwin University, ${ }^{2}$ Center for International Forestry Research, ${ }^{3}$ University of Papua New Guinea, ${ }^{4}$ Northeastern Illinois University,

${ }^{5}$ University of Leeds, School of Earth and Environment 
al. 2009, Fox et al. 2010), illegal forest clearance under the guise of agricultural development (Filer 2011, 2012), and corruption (Transparency International 2009, 2011, Laurance et al. 2011). These features are often associated with a lack of state autonomy from what can be considered as powerful vested interests driving deforestation and forest degradation, particularly foreign-owned logging companies (Laurance 2010, Melick 2010, Laurance et al. 2011).

These features of forest governance in $\mathrm{PNG}$ are a reflection of broader governance conditions within the country. In 2013, PNG ranked 144 out of 177 countries in Transparency International's Corruption Perceptions Index (Transparency International 2013) and is categorized as a "flawed democracy" (Kekic 2007). A major challenge for good governance in PNG has been reconciling the myriad traditional local political systems based on custom and culture with the Westminster-style system of government that was inherited at independence in 1975 (Allen and Hasnain 2010, Gelu 2010). Since independence, no single political party has ever received enough votes at a national election to govern in its own right, leading to the formation of large and unruly coalitions based less on shared ideology and more on gaining or maintaining power (Gelu 2010). Patronage politics together with ethnolinguistic fragmentation are suggested as underlying reasons why PNG has failed to transform its vast natural resource wealth into broad-based improvements in social indicators (Allen and Hasnain 2010).

Local communities are key stakeholders in forest governance in PNG. Around $97 \%$ of the total land area and virtually all forests are owned by kinship groups and managed according to local custom (National Research Institute 2007, Overseas Development Institute 2007). In practice, however, many customary landowners are not aware of their rights and therefore are vulnerable to exploitation. The benefits from logging are often concentrated in the hands of political elites at the local and national level, who are accused of colluding with foreign logging companies and using their positions for personal gain rather than acting in the local interest (Filer and Sekran 1998, Overseas Development Institute 2007, Laurance 2010).

In this context of strong de jure but weak de facto customary land rights, a lack of government autonomy from powerful vested interests, and formidable drivers of deforestation, there is a real need for governance reforms if REDD+ is to be effective and reduce forest carbon emissions in PNG. Governance reforms may include more transparent and participatory policy processes, functioning multistakeholder governance arrangements, attention to equity including procedural equity, e.g., the free, prior, and informed consent of customary landowners, and distributive equity, e.g., equitable benefit-sharing arrangements (Di Gregorio et al. 2013), and a review of existing or planned policies that enable deforestation. If well designed and properly implemented, such measures could facilitate the transformational change needed to reduce deforestation and forest degradation in PNG (Melick 2010).

\section{Evolution of REDD+ in PNG}

The governments of PNG and Costa Rica proposed the concept of Reducing Emissions from Deforestation (then known as RED) at the 11th Conference of the Parties to the United Nations Framework Convention on Climate Change (UNFCCC) in 2005.
In their submission, they acknowledged the contribution of tropical deforestation in developing countries to global carbon emissions, but suggested that:

\begin{abstract}
In the absence of revenue streams from standing forests, communities and governments in many developing countries have little incentive to prevent deforestation... without a more complete market valuation, standing forests cannot overcome the economic opportunity cost associated with their conservation. (Governments of Papua New Guinea and Costa Rica 2005)
\end{abstract}

The government of PNG has continued to be a leading international proponent of REDD+ (Somare 2005, 2010). However, efforts aimed at achieving "REDD+ readiness" in PNG have encountered numerous challenges. Work on a national REDD+ strategy and associated institutional arrangements in 2008-2009 was marred by questions about the legal status of the newly established Office of Climate Change and its legitimacy to centrally manage REDD+, concerns about poor stakeholder engagement and national ownership of REDD+ policy processes, and media reports that "carbon cowboys" were exploiting the policy vacuum to preemptively secure forest carbon rights from customary landowners (Melick 2010, Babon et al. 2012; P. Chatterton, Review of the UN-REDD joint program in Papua New Guinea, unpublished manuscript).

National REDD+ policy development during this period was driven by two high-profile policy entrepreneurs (Mintrom and Vergari 1996): Sir Michael Somare, Prime Minister of PNG from 2002 to 2011, and Kevin Conrad, head of the Coalition for Rainforest Nations and PNG's UN Special Envoy and Ambassador for Climate Change. These two individuals worked to sell the idea of REDD+ nationally and internationally and exerted a "policy monopoly" (Baumgartner and Jones 1993) at the national level by authoritatively defining deforestation and forest degradation as a result of market failures, thus effectively restricting policy responses to finding ways to "value forests more alive than dead" (Somare 2010:1).

Somare and Conrad's monopoly over the REDD+ agenda in $\mathrm{PNG}$, their engagement of international consulting firm McKinsey \& Company to draft PNG's national climatecompatible development strategy, and a lack of community consultation triggered calls from nongovernmental organizations (NGOs) and academics for greater transparency and participation in REDD+ policy processes, and for the inclusion of social and environmental safeguards, particularly to protect the rights of customary landowners (Bingeding 2009, EcoForestry Forum 2010, Greenpeace 2010).

In response to these calls, a multistakeholder governance structure was established in March 2010 to coordinate action on climate change (Babon and Gowae 2013). A whole-of-government National Climate Change Committee was established as the main decision-making body for climate change policy, with a restructured Office of Climate Change and Development (OCCD) to act as the main coordinating body for climate change issues (Office of Climate Change and Development 2011). At the same time, a multistakeholder technical working group on REDD+ was convened with membership from government agencies, NGOs, donors, and industry associations. The Papua 
New Guinea Forest Authority, the main state actor responsible for forest management, would oversee a number of pilot projects throughout the country to try various REDD+ strategies, including reduced-impact logging, secondary forest management, and forest conservation. Five province-level pilot projects have been officially endorsed by the government of PNG, although most are still in the readiness phase (Office of Climate Change and Development 2012).

A period of political turmoil in PNG beginning in late 2011 and culminating in a national election in June 2012 saw both Somare and Conrad leaving office. A new Ministry of Forests and Climate Change was created, to which the OCCD now reports rather than to the Prime Minister. The full implications of this change are yet to be seen, but it is worth noting that other countries such as Indonesia (Indrarto et al. 2012) have tended to separate responsibility for climate change policy and responsibility for forest policy. This separation of powers may alleviate possible conflicts of interest and path dependencies that favor forest exploitation and existing forest industries over forest conservation. Given the turbulent evolution of REDD+ in PNG, the departure of prominent REDD+ policy entrepreneurs, and an almost complete reconfiguration of individual actors in the REDD+ policy domain following the ousting of Somare, questions remain regarding the existence and influence of coalitions for transformational change that could induce improved forest governance and result in REDD+ outcomes.

\section{Theoretical framework}

We drew on the ACF developed by Sabatier and Jenkins-Smith (1993) to investigate the presence and influence of coalitions of actors advocating for transformational change in forest policy in PNG. The ACF was developed as a systems-based model of policy change within policy domains characterized by technical complexity or uncertainty, multiple actors, and competing belief systems (Sabatier and Weible 2007). As described by Ingold and Varone (2012:321), the ACF "views the policy process as a competition between coalitions of actors who advocate beliefs about policy problems and solutions." The value of the ACF in our study lay in its ability to explain the dynamic nature and uneven power relations characteristic of the governance of socialecological systems in developing countries. In particular, we found that the ACF provided a useful model for explaining the formulation of policy coalitions (Bulkeley 2000, Weible 2005) and exploring the role of policy entrepreneurs (Mintrom and Vergari 1996) and policy learning (Weible 2006) in driving policy change.

The ACF posits that actors in a given policy domain form advocacy coalitions to influence government policy and achieve common objectives (Weible 2005, Weible and Sabatier 2005, Ingold 2011). Advocacy coalitions are composed of actors who "share a set of normative and causal beliefs" and are engaged in "a non-trivial degree of co-ordinated activity over time" (Sabatier 1998:103). Although members of an advocacy coalition may disagree on secondary beliefs such as the details of a particular policy, they will agree on fundamental aspects, termed "policy core beliefs" (Sabatier 1998:103). The relative importance given to economic development versus environmental protection is one example of a policy core belief (Sabatier 1998). Most policy domains have a dominant advocacy coalition, which is relatively successful in translating its goals and beliefs into policy, and one or more minority advocacy coalitions (Sabatier and JenkinsSmith 1993).

The ACF predicts that major policy change will occur only if there is a change in the beliefs of the dominant coalition or changes in available resources. Coalition resources include access to legal authority to make policy decisions, information, supporters, financial resources, and skillful leadership (Weible 2006). Changes in policy beliefs and resources can be brought about in four ways: external shocks, policy-oriented learning, internal events, or negotiated agreements (Weible et al. 2009). We used the ACF to assess the extent to which the emergence of $\mathrm{REDD}+$ at the international level, an external event as defined by the ACF, has provided a catalyst for transformational change in PNG, and whether the internal dynamics of the national REDD+ policy domain are likely to constrain or enable such change.

Our focus was on identifying advocacy coalitions based on shared policy core beliefs, particularly the creation of transparent, accountable, multiactor governance arrangements for REDD+. Although governance is just one aspect of transformational change, we selected this focus because of PNG's history of poor forest governance and its documented relationship to the drivers of deforestation and forest degradation (Papua New Guinea Commission of Inquiry into Aspects of the Forest Industry et al. 1990, Forest Trends 2006, International Tropical Timber Council 2007, Overseas Development Institute 2007).

Because this study sought to identify and analyze the role of advocacy coalitions in REDD+ policy networks and policy change, we used perceived influence as a measure of reputational power (Kriesi et al. 2006) and an indication of a coalition's power to translate its beliefs into formal policy. This approach has been effectively applied by several authors (Zafonte and Sabatier 1998, Weible 2005, 2006, Weible and Sabatier 2005). We used this measure because it allowed us to assess the potential for a coalition calling for transformational change to become dominant in PNG.

This study adds to nascent applications of the ACF in developing countries and is notable for its robust data collection methods (Weible et al. 2009, 2011). A particularly novel aspect of this study is the effort to identify more than two advocacy coalitions within the national REDD+ policy domain. By identifying coalitions within coalitions, this study adds nuance to the analysis and helps avoid any assumptions of "homogeneity in group members either in beliefs or in coordination patterns" cautioned against by Weible et al. (2009:130).

\section{METHODS}

Identifying policy actors in the national REDD+ policy domain We began by identifying the policy actors involved in the national REDD+ policy domain in PNG. Following Knoke et al. (1996), the main focus of our study was on formal organizations, i.e., organizational actors, rather than individual actors. We also drew on Laumann and Knoke (1987) and Brockhaus and Di Gregorio (2012) in our definition of REDD+ policy actors as all organizations perceived by others to be, and that consider themselves to be, to be a part of the REDD+ policy domain, able to influence to a greater or lesser degree the agenda setting, formulation, and implementation of national REDD+ policies. 
An initial list of organizations that may be part of the national REDD+ policy domain in PNG was identified based on a review of relevant literature, including peer-reviewed articles, media reports, and publicly available documents such as government and NGO reports, meeting minutes, workshop attendance lists, and so forth. Through this process an initial list of 40 organizational actors was identified. This list was reviewed by an expert panel consisting of five individuals representing the government, the private sector, NGOs, donors, and academia. They suggested a number of additional organizational actors, taking the list to 74. Following Saunders (2007), we also applied the criterion of mutual relevance (Laumann and Knoke 1987) and if actors did not consider themselves to be part of the REDD+ policy domain when contacted to participate in the study, they were removed from the list. The final list consisted of 66 organizational actors. We grouped actors into seven organizational categories: government, research institutions, private sector, national NGOs, international NGOs, other international organizations, and bilateral or multilateral aid donors (see Appendix 1 for details about policy actors by actor group).

\section{Data collection and analytical methods}

We used three methods to collect data on an organization's policy core beliefs relating to REDD+: (1) social organization survey, (2) semistructured interviews, and (3) document review.

A high-level representative of each of the 66 organizations identified as part of the national REDD+ policy domain was contacted to participate in a face-to-face survey and semistructured interview as part of the research. Of the 66 organizations identified as REDD+ policy actors, 45 representatives completed the survey for a response rate of $68 \%$. Government and private sector actors were under-represented in the survey data compared with other actor groups, with a response rate of $58 \%$ and $42 \%$, respectively, which was mainly because of lack of response despite repeated attempts to contact the organization rather than outright refusal to participate in the research. Several factors were likely to have influenced the survey response rate. First, survey data were collected from November 2011 to June 2012, which coincided with a period of political turmoil in PNG. During this time, there was considerable ambiguity regarding government leadership positions, and some organizational actors, particularly state actors, were essentially on hiatus until scheduled general elections took place in July 2012 and were unable to be contacted. Second, REDD+ is regarded as a sensitive issue and some actors may have been reluctant to share what was considered confidential information.

Semistructured interviews were conducted with representatives of 28 organizational actors from October 2011 to March 2012. Time constraints meant that not all organizational actors were asked to participate in an interview because priority was given to the survey. However, interviews were conducted with key actors across all actor groups.

To triangulate the survey and interview data and address the limitation of survey nonresponses, information on REDD+ policy core beliefs was also obtained from publicly available material. Document review included a systematic analysis of national print media articles published between 2005 and 2010, content analysis of an organization's website or published reports including speeches, and policy positions of formal coalitions or representative bodies.

To identify REDD+ policy core beliefs, we drew on the typology of belief systems outlined in Sabatier (1998). This typology provides 10 illustrative components of policy core beliefs, including 2 "fundamental normative beliefs": (1) orientation on basic value priorities and (2) identification of groups/entities whose welfare is of concern; and eight "empirical components": (3) the overall seriousness of the problem, (4) basic causes of the problem, (5) proper distribution of authority between government and the market, (6) proper distribution of authority among levels of government, (7) priority accorded various policy instruments, (8) method of financing, (9) ability of society to solve the problem, and (10) participation of public versus experts versus elected officials (Sabatier 1998:12-13).

Drawing on the typology of policy beliefs outlined above, and our interview and survey data, we used an iterative inductivedeductive process to identify six REDD+ policy core beliefs that could be used to allocate organizational actors into advocacy coalitions based on shared beliefs: (1) importance of tackling drivers of deforestation and degradation, (2) need for structural and/or governance reforms, (3) promoting the rights of and benefits for forest-dependent peoples/customary landowners, (4) promoting evidence-based policy, (5) the need for multiactor and multilevel, including decentralized, governance, and (6) use of market-based mechanisms. Using these six precepts, we identified four initial advocacy coalitions within the national REDD+ policy domain that we named Status Quo, Carbon Entrepreneurs, Sustainable Livelihoods, and Sustainable Development (Table 1). Actors were assigned to a particular advocacy coalition if their policy core beliefs were consistent with all or a majority of the precepts defining that coalition.

For this study, we used qualitative data such as meeting minutes, group membership, and participant observation to assess whether the advocacy coalitions we identified based on shared beliefs also engaged in coordinated activities. We also drew on our qualitative data to provide information on the main REDD + policy demands of each advocacy coalition, as well as policy resources (Weible 2006, Sabatier and Weible 2007) held by members and made available to advocacy coalitions, such as financial resources, information, formal authority to make policy decisions, public opinion, and so forth.

We then calculated the perceived influence, or reputational power (Kriesi et al. 2006), of each organizational actor. Organizations participating in the survey were provided with a list of all 66 organizational actors within the national REDD+ policy domain with the following instruction: "Please indicate those organizations that stand out as especially influential on domestic REDD+ policies." The reputational power of any given organization was based on the percentage of survey respondents that identified that organization as being especially influential. Following Kriesi and Jegen (2001), we calculated the reputational power of each advocacy coalition based on the average perceived influence of all coalition members. We conducted a difference of means ( $\mathrm{t}$ ) test, using 10,000 permutations of our influence data, to test the difference between the influence levels of the coalitions. 
Table 1. Criteria used to assign actors to coalitions.

\begin{tabular}{|c|c|c|c|c|c|c|}
\hline $\begin{array}{l}\text { Advocacy } \\
\text { coalition }\end{array}$ & $\begin{array}{c}\text { Actively } \\
\text { promoting } \\
\text { tackling drivers } \\
\text { of deforestation } \\
\text { and degradation }\end{array}$ & $\begin{array}{l}\text { Actively } \\
\text { promoting } \\
\text { structural and/or } \\
\text { governance } \\
\text { reforms }\end{array}$ & $\begin{array}{l}\text { Actively promoting } \\
\text { rights of and benefits } \\
\text { for forest-dependent } \\
\text { peoples/customary } \\
\text { landowners }\end{array}$ & $\begin{array}{c}\text { Actively } \\
\text { promoting } \\
\text { evidence- } \\
\text { based policy }\end{array}$ & $\begin{array}{l}\text { Actively } \\
\text { promoting } \\
\text { multiactor, } \\
\text { multilevel } \\
\text { (including } \\
\text { decentralized) } \\
\text { governance }\end{array}$ & $\begin{array}{c}\text { Actively } \\
\text { promoting } \\
\text { market-based } \\
\text { mechanisms }\end{array}$ \\
\hline Status Quo & No & No & No & N/A & No & N/A \\
\hline $\begin{array}{l}\text { Carbon } \\
\text { Entrepreneurs }\end{array}$ & No & No & Some & N/A & Some & Yes \\
\hline $\begin{array}{l}\text { Sustainable } \\
\text { Livelihoods }\end{array}$ & Yes & Yes & Yes & Yes & Yes & No \\
\hline $\begin{array}{l}\text { Sustainable } \\
\text { Development }\end{array}$ & Yes & Yes & Some & Yes & Some & Some \\
\hline
\end{tabular}

This statistical test was conducted using R 3.0 (R Core Team 2013), and data were visualized using ggplot2 (Wickham 2009), also in $\mathrm{R} 3.0$.

\section{RESULTS}

\section{Advocacy coalitions for transformational change}

We found evidence of two advocacy coalitions promoting transformational change in the REDD+ policy domain in PNG, which we labeled the Sustainable Livelihoods and the Sustainable Development coalitions (Table 2). Among members of the Sustainable Development coalition, beliefs and interests with regard to REDD+ are highly diverse. Members understand REDD+ as a vehicle to support Sustainable Development, low carbon growth/green growth, biodiversity conservation, and evidence-based policy. They advocate governance reforms for pragmatic rather than ideological reasons, for example, bringing PNG into line with international standards for accessing international funding, markets, and/or certification schemes. It is the most diverse advocacy coalition in the REDD+ policy domain, with members including state actors, international NGOs, research institutions, bilateral and multilateral donors, private-sector actors, and an international organization. Despite this organizational diversity, the coalition is dominated numerically by international actors, particularly bilateral donors and NGOs, and both domestic and international research institutions, which bring financial resources and information to the coalition (Table 2). It also includes two state actors, the OCCD and the Department of Environment and Conservation, which have formal decision-making authority.

The Sustainable Livelihoods coalition consists of international and domestic NGOs and one private-sector actor involved in REDD+ as part of its Corporate Social Responsibility initiative. Primarily concerned with the rights of customary landowners, this coalition promotes rights and community-based approaches to REDD+, advocating for social and environmental safeguards, multistakeholder governance, information and awareness raising for customary landowners, and equitable benefit-sharing arrangements. The coalition's position on the rights of customary landowners is particularly salient among the public, thus earning it resources in terms of public opinion and potential supporters that can be mobilized. Many of the domestic NGOs also have links with international networks, which bring information and financial resources to the coalition.

Together, the Sustainable Livelihoods and Sustainable Development advocacy coalitions promote many aspects of transformational change. However, the two coalitions do hold different policy core beliefs. For example, they differ in their beliefs regarding "groups or other entities whose welfare is of greatest concern" (Sabatier 1998:112). The Sustainable Livelihoods coalition is mainly concerned with how REDD+ will affect the welfare and rights of customary landowners, whereas the Sustainable Development coalition focuses broadly on the national interest. However, they share many secondary beliefs around improved forest governance.

\section{Advocacy coalitions supporting business as usual}

We also identified two business-as-usual advocacy coalitions, which we labeled Status Quo and Carbon Entrepreneurs. Neither coalition actively promotes transformational change in forest governance that would be needed to achieve REDD+ outcomes.

The Status Quo advocacy coalition consists of organizations seeking to maintain or extend their existing control over or access to forest resources, rather than aiming to reduce deforestation and forest degradation. This coalition consists of government and private-sector actors. Organizations in this coalition, e.g., logging companies, may be directly involved in activities leading to deforestation or forest degradation; others may indirectly support forest loss by promoting narrow sectoral interests such as agricultural expansion or by delegating policy implementation to others without adequate resources or capacity, and they may have conflicts of interest that reduce their ability to make decisions independently of the main actors driving deforestation and forest degradation. Organizations in this coalition may be directly involved in activities leading to deforestation or forest degradation; they may indirectly support forest loss by promoting narrow sectoral interests such as agricultural expansion; they may delegate policy implementation to others without adequate resources or capacity; or they may have conflicts of interest that reduce their ability to make decisions independently of the main actors driving deforestation and forest degradation. More than 
Table 2. Advocacy coalitions in the REDD+ policy domain in Papua New Guinea.

\begin{tabular}{|c|c|c|c|c|}
\hline $\begin{array}{l}\text { Advocacy } \\
\text { coalitions } \\
\text { (promoting } \\
\text { transformational } \\
\text { change [TC] or }\end{array}$ & $\begin{array}{l}\text { Influence score } \\
\text { (percentage of } \\
\text { policy actors } \\
\text { that nominated } \\
\text { this coalition) }\end{array}$ & REDD+ policy preferences & $\begin{array}{l}\text { Coalition resources } \\
\text { (adapted from Weible } \\
\text { [2006] and Sabatier } \\
\text { and Weible [2007]) }\end{array}$ & $\begin{array}{l}\text { Coalition members } \\
\text { (number of organizations out of } \\
\text { actor group; percentage of actor } \\
\text { group) }\end{array}$ \\
\hline
\end{tabular}

change [TC] or this coalition)

business as usual

[BAU])

Sustainable

development

(TC)

$14.33(32 \%)$

-That REDD+ covers opportunity
costs of forest conservation
-Economic diversification/“green
growth”
-Governance and institutional
reform
-Evidence-based/good public policy

- Formal legal authority to make policy decisions

-Information

-Financial resources

reform

ased public policy

Sustainable $\quad 14.00(31 \%)$

livelihoods

(TC)

Status quo

$20.42(45 \%)$

(BAU)

Carbon

$12.33(27 \%)$

entrepreneurs

(BAU)
-Social and environmental

safeguards

-Multistakeholder governance

-Information and awareness raising

for resource owners

-Equitable benefit-sharing

arrangements

-Community-based REDD+

- No halt to commercial logging

- Reduced impact logging/secondary forest management as part of

REDD+

-No voluntary carbon projects

- Central government coordination/

control

-Minimal conditions on

international funds

-Policy to support voluntary carbon projects

-Little central government control/

oversight (projects negotiated

directly

with resource owners)

-No focus on governance reforms or

building enabling environment
-Information

-Financial resources
-Public opinion

-Information

-Supporters that can

be mobilized

-Formal legal

authority to make

policy decisions

-Information

- Financial resources

-Government ( $\mathrm{n}=8 ; 67 \%)$

-Private sector $(n=4 ; 33 \%)$

\author{
- Donors $(\mathrm{n}=10 ; 100 \%)$ \\ - Research institutions $(\mathrm{n}=8$; \\ $100 \%$ ) \\ -Domestic NGOs ( $\mathrm{n}=5 ; 50 \%)$ \\ -Int. NGOs ( $\mathrm{n}=5 ; 50 \%)$ \\ - Government ( $\mathrm{n}=3 ; 25 \%)$ \\ -Private sector $(\mathrm{n}=3 ; 25 \%)$ \\ -Int. organizations $(n=1 ; 50 \%)$ \\ -Domestic NGOs ( $\mathrm{n}=9 ; 75 \%)$ \\ -International NGOs $(\mathrm{n}=5 ; 50 \%)$ \\ -Private sector $(\mathrm{n}=1 ; 8 \%)$
}

-Private sector $(\mathrm{n}=4 ; 33 \%)$

-International organizations

$(\mathrm{n}=1 ; 50 \%)$

- Government $(\mathrm{n}=1 ; 8 \%)$ two-thirds of all government actors in the REDD+ policy domain are in this coalition, and several members of this coalition have legal authority to make policy decisions. One such member is the Papua New Guinea Forest Authority, which despite developing a forest and climate change policy incorporating REDD+, still promotes business-as-usual industrial-scale logging for export. Private-sector actors in this advocacy coalition include the PNG Forest Industry Association and the largest logging company in the country, Rimbunan Hijau, which contribute financial resources and information to the coalition.
Members of the Carbon Entrepreneurs advocacy coalition largely seek personal gain through carbon trading, e.g., financial, reputational, early-adopter advantage, and so forth, with little interest in securing long-term carbon emission reductions. Members of this coalition promote the use of market-based instruments for REDD+, particularly voluntary carbon markets, and include so-called carbon cowboys as well as more legitimate organizations promoting market-based mechanisms for REDD+. It is important to note that not all actors that support market-based mechanisms fall into the Carbon Entrepreneurs 
advocacy coalition. This coalition is characterized by its focus on short-term individual gain rather than on governance reforms capable of securing permanent REDD+ outcomes for broader societal welfare. No member of this coalition has formal decisionmaking authority.

Although both these advocacy coalitions support aspects of business as usual, they differ in their policy core beliefs, such as the appropriate distribution of authority between government and the market (Sabatier 1998). For example, some members of the Status Quo coalition support REDD+ as part of an international compliance market under the UNFCCC and do not support the development of forest carbon projects in PNG for the voluntary market (Somare 2009, Gridneff 2010). By contrast, most members of the Carbon Entrepreneurs coalition support voluntary carbon markets and are critical of central government control over REDD+ (Talu 2009).

\section{Reputational power of advocacy coalitions in the REDD+ policy} domain

We calculated the reputational power of each advocacy coalition to consider the potential for the coalitions to translate their beliefs and interests into formal policy. The Status Quo coalition has the highest reputational power within the national REDD+ policy domain, with coalition members on average deemed especially influential by $45 \%$ of survey respondents. The Sustainable Development and Sustainable Livelihoods advocacy coalitions have similar levels of power, with mean influence scores of $32 \%$ and $31 \%$, respectively. The Carbon Entrepreneurs coalition has the lowest reputational power, perceived as especially influential by $27 \%$ of survey respondents (Table 1 ).

A comparison of the mean perceived influence scores of the two most influential advocacy coalitions, Status Quo and Sustainable Development, shows that the Status Quo coalition had a significantly higher mean influence score than the Sustainable Development coalition $(\mathrm{t}=1.9273 ; \mathrm{P}$ value based on 10,000 permutations of the groups $=0.025)$, suggesting its reputational power is significantly greater than that of the other advocacy coalitions present in the national REDD+ policy domain. In turn, this suggests that the Status Quo coalition holds greater power to have its interests and beliefs reflected in formal policy.

Mean perceived influence is just one measure of a coalition's power, however. It is important to consider that the Sustainable Development coalition is numerically dominant and counts among its members the organization considered most influential, the OCCD, which is responsible for REDD+ policy development and coordination and is perceived as being especially influential by $87 \%$ of respondents (Fig. 1). The Sustainable Livelihoods coalition counts among its members the second most influential organization, the Eco-Forestry Forum, which is perceived as being especially influential by $80 \%$ of respondents. Coalitions for transformational change, in other words, are both numerically dominant and contain two of the three most influential organizations.

\section{DISCUSSION}

Our analysis of the national REDD+ policy domain identified two distinct advocacy coalitions promoting transformational change in forest governance in PNG: Sustainable Development and Sustainable Livelihoods. However, our reputational power
Fig. 1. Perceived influence of REDD+ advocacy coalitions in Papua New Guinea.

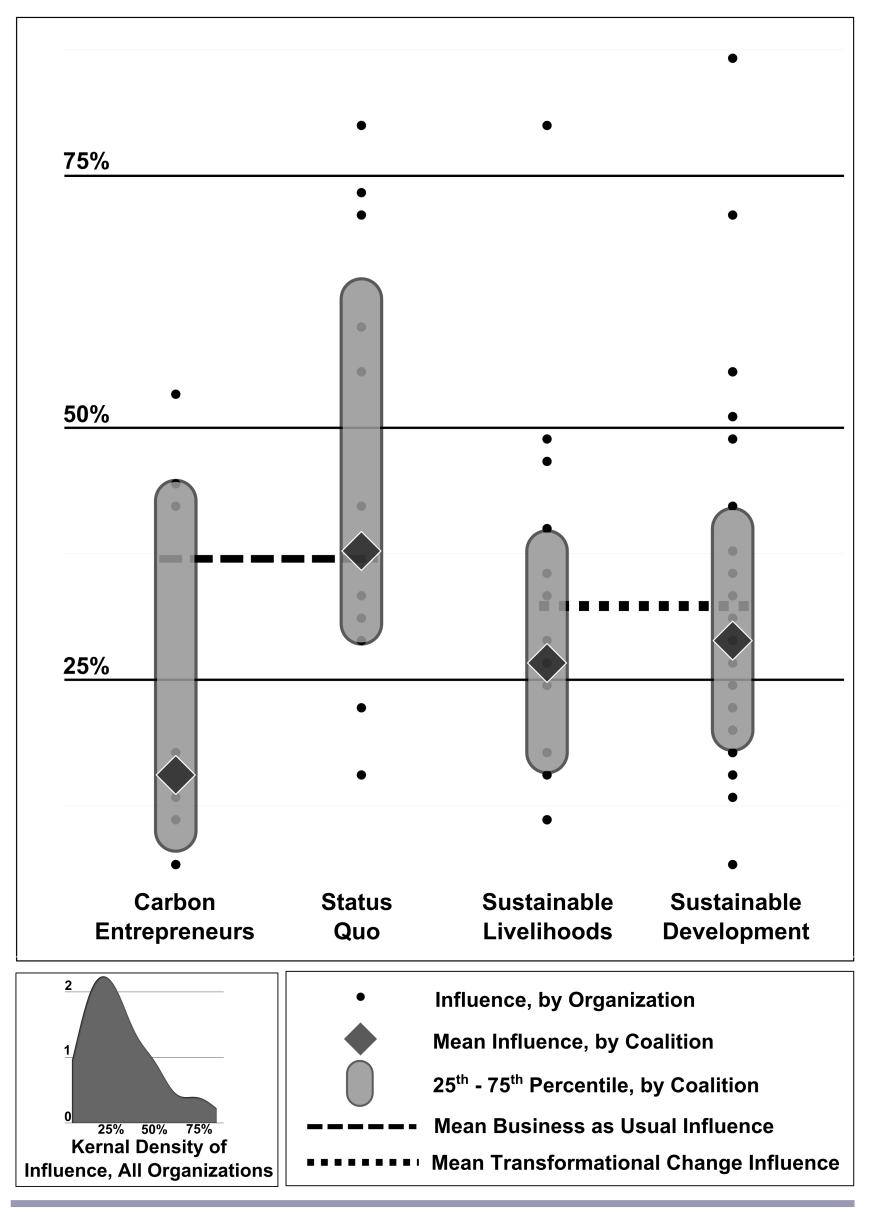

analysis suggests they are currently minority advocacy coalitions and are not sufficiently powerful to challenge business-as-usual interests responsible for deforestation and forest degradation in PNG.

Status Quo, the dominant advocacy coalition in the REDD+ policy domain, promotes many aspects of business as usual and wields the most influence over the national REDD+ policy domain. We suggest that the potential for transformational change in PNG is currently constrained by this advocacy coalition. In particular, private-sector actors within this advocacy coalition wield considerable political influence and are seen as a key barrier to transformational change, with one interviewee stating of the largest logging company in the country, Rimbunan Hijau: "they run forestry in this country, they run the local biggest newspaper, they are one of the biggest employers in the country, they have enormous political power." (Interview with an NGO representative, 10 February 2012)

By contrast, we found that members of the Carbon Entrepreneurs advocacy coalition, which also promote elements of business as usual, have the least influence over national REDD+ policies. Even though some members of this coalition were highly visible within the public debate on REDD+, they struggled to 
institutionalize their interests in national REDD+ policy processes. Indeed, many of its members have largely disappeared as organizational actors from the national REDD+ policy domain. This is significant, because some of these organizations appeared to wield considerable influence over initial national REDD+ policy processes in PNG between 2008 and 2010 (Babon 2011), including the policy monopoly exerted by Somare and Conrad.

It now appears that the early REDD+ policy entrepreneurs have little continuing influence over national REDD+ policies, and the policy monopoly once exerted by a small group of policy elites has been replaced by more open, transparent, and participatory decision making. Indeed, many interviewees across actor groups acknowledged that the OCCD had become more open and consultative over time, and commended the functioning of OCCD's Technical Working Groups. Interviews suggest a number of reasons for the shift toward greater stakeholder participation in REDD+ policy processes: public pressure from NGOs and donors, the change in government leadership in late 2011 and resulting breakup of the policy monopoly that had previously dominated the government's climate change activities, the departure of McKinsey \& Company as strategic advisors to the government on climate change and REDD+, and awareness of the damage done to PNG's international reputation by the poor governance of REDD+ under the early incarnations of the Office of Climate Change. These developments can be interpreted as a further indication of what our analysis suggests: despite the current dominance of business-as-usual interests in the national REDD+ policy domain, some potential pathways to transformational change may be open in PNG.

First, the Sustainable Development advocacy coalition has been somewhat successful in translating its policy preferences into formal policy, both within and outside the forest policy domain. For example, one of the seven pillars of PNG's long-term national strategy released in 2010 is Environmental Sustainability and Climate Change and includes a number of goals related to REDD+ (National Strategic Plan Taskforce 2010). However, there is still considerable policy inconsistency to resolve, with one interviewee suggesting:

The country currently has an ambiguous position. On the one hand, very large scale logging operations are happening; on the other hand, the country being very willing to receive some $R E D D+$ funding and to put in place a REDD+ system. So I think they will eventually have to come to sorting out these two extreme points.

(Interview with a donor representative, 14 February 2012)

Another potential pathway to transformational change is through the building of "coalitions of convenience" that can bring additional resources to minority coalitions. There is already evidence of an unlikely alliance between the oil palm industry and civil society organizations, which were previously at odds over the social and environmental impacts of oil palm development in PNG. They have formed a coalition of convenience to oppose the allocation of Special Agriculture and Business Leases, which are granted ostensibly for agricultural development, but are widely believed to be misused as a vehicle for timber extraction by a "virtual" oil palm industry (Filer 2012, Greenpeace 2012). Newly emerging coalitions of convenience with incoming allies that bring additional resources or can negotiate agreements over common problems provide two additional pathways to transformational change. The moratorium and Commission of Inquiry into Special Agriculture and Business Leases announced by the government of PNG in July 2011 may be an example of a negotiated agreement between coalitions on both sides to tackle this particular driver of deforestation.

The final potential pathway to transformational change comes through policy-oriented learning that can lead to changes in policy core beliefs within the dominant advocacy coalition. For example, the Papua New Guinea Forest Authority, a key member of the Status Quo advocacy coalition, has developed a climate change policy and established a REDD+ and Climate Change Branch, and is leading the establishment of REDD+ pilot projects. Policy learning arising from these sorts of activities and exposure to new ideas and incentives have the potential to reorient the Papua New Guinea Forest Authority so that it comes to support a wider range of options for forest use and management, rather than maintaining its current dominant focus on managing forests for commercial logging. However, like Sabatier (1998), we believe that realizing these potential pathways will require skillful leadership to exploit opportunities and build cohesive and powerful coalitions that can challenge dominant business-asusual interests and achieve policy change.

\section{CONCLUSION}

PNG's early interest in and active promotion of REDD+ at the international level have been followed by only modest changes in national policy and practice. Our findings clearly suggest that, despite the early presence of high-profile REDD+ policy entrepreneurs and the government's pro-REDD+ position at the international level, the most powerful coalition of actors in the domestic policy sphere continues to defend existing institutional structures that support business as usual, particularly unsustainable rates of commercial timber harvesting and largescale forest clearance under the guise of agricultural development.

We found that the two advocacy coalitions calling for transformational change remain minority coalitions. Although the emergence of REDD+ as an idea has strengthened the resources of these two coalitions through the development of coalitions of convenience and the provision of additional resources, their influence remains insufficient to effectively challenge the dominance of the business-as-usual coalition. However, we suggest there is some cause for optimism given several characteristics of the REDD+ policy domain that have the potential to challenge existing power relations, including (1) the growing power of transformational change coalitions, in part through the rising salience and relevance of their beliefs as well as through enlisting powerful new members; (2) the merging of coalitions based on emerging shared beliefs and objectives, e.g., green growth; and (3) policy-oriented learning and resulting changes in policy preferences of individual business-as-usual actors.

Responses to this article can be read online at: http://www.ecologyandsociety.org/issues/responses. $\mathrm{php} / 6486$ 


\section{Acknowledgments:}

The data and analysis presented in this paper are part of the policy component of the Center for International Forestry Research (CIFOR) global comparative study on REDD+. Parts of the methodology were adapted from the research protocol for media and network analysis designed by Comparing Climate Change Policy Networks. We gratefully acknowledge the financial support received from the Norwegian Agency for Development Cooperation, the Australian Agency for International Development, the UK Department for International Development, and the European Commission. We thank Christine Wairata, Sofi Mardiah, Nidatha Martin, and Abel Simon for their invaluable research support, and Imogen Bagery-Parker and CIFOR's communications team for their editing support. We would also like to thank two anonymous reviewers for their particularly constructive and insightful comments.

\section{LITERATURE CITED}

Allen, M., and Z. Hasnain. 2010. Power, pork and political patronage: decentralisation and the politicisation of the development budget in Papua New Guinea. Commonwealth Journal of Local Governance 6:7-31.

Angelsen, A., M. Brockhaus, M. Kanninen, E. Sills, W. D. Sunderlin, and S. Wertz-Kanounnikoff, editors. 2009. Realising REDD+: national strategy and policy options. Center for International Forestry Research, Bogor, Indonesia.

Babon, A. 2011. Snapshot of REDD+ in Papua New Guinea. Infobrief 40. Center for International Forestry Research, Bogor, Indonesia.

Babon, A., and G. Y. Gowae. 2013. The context of REDD+ in Papua New Guinea: drivers, agents and institutions. CIFOR Occasional Paper 89. Center for International Forestry Research, Bogor, Indonesia.

Babon, A., D. McIntyre, and R. Sofe. 2012. REDD+ politics in the media: a case study from Papua New Guinea. CIFOR Working Paper 97. Center for International Forestry Research, Bogor, Indonesia.

Baumgartner, F. R., and B. D. Jones. 1993. Agendas and instability in American Politics. University of Chicago Press, Chicago, Illinois, USA.

Bingeding, N. 2009. Carbon trade-which way PNG? Page 16. Post-Courier. 22 April.

Brockhaus, M., and A. Angelsen. 2012. Seeing REDD+ through the 4 Is: a political economy framework. Pages 15-30 in A. Angelsen, M. Brockhaus, W. D. Sunderlin, and L. V. Verchot, editors. Analysing REDD+: challenges and choices. Center for International Forestry Research, Bogor, Indonesia.

Brockhaus, M., and M. Di Gregorio. 2012. A brief overview: component 1 on national REDD+ policies and processes. CIFOR Infobrief No. 13. Center for International Forestry Research, Bogor, Indonesia.

Bulkeley, H. 2000. Discourse coalitions and the Australian climate change policy network. Environment and Planning C: Government and Policy 18(6):727-748. http://dx.doi.org/10.1068/c9905j
Bun, Y., T. King, and P. Shearman. 2004. China's impact on Papua New Guinea's forestry industry. Forest Trends, Washington D.C., USA. [online] URL: http://www.forest-trends.org/documents/ files/doc 154.pdf

Di Gregorio, M., M. Brockhaus, T. Cronin, E. Muharrom, L. Santoso, S. Mardiah, and M. Büdenbender. 2013. Equity and REDD+ in the media: a comparative analysis of policy discourses. Ecology and Society 18(2): 39. http://dx.doi. org/10.5751/ES-05694-180239

Eco-Forestry Forum (EFF). 2010. PNG EFF's comments and conditional endorsement for the PNG national joint program to the UNREDD Policy Board. Papua New Guinea Eco-Forestry Forum, Boroko, Papua New Guinea. [online] URL: http://www. globalwitness.org/sites/default/files/PNG $\% 20$ EFF $\% 20$ comments $\%$ 20 on $\% 20$ PNG $\% 20$ National $\% 20$ Programme $\% 20$ PB $5 \% 20$ Nov $\% 203-5 \%$ 202010.pdf

Fearnside, P. M. 2000. Global warming and tropical land-use change: greenhouse gas emissions from biomass burning, decomposition and soils in forest conversion, shifting cultivation and secondary vegetation. Climatic Change 46(1-2):115-158. http://dx.doi.org//10.1023/A:1005569915357

Fearnside, P. M. 2012. Brazil's Amazon forest in mitigating global warming: unresolved controversies. Climate Policy 12(1):70-81. http://dx.doi.org//10.1080/14693062.2011.581571

Filer, C. 2011. The new land grab in Papua New Guinea. Paper presented at the International conference on Global Land Grabbing, Institute of Development Studies, Sussex, UK. [online] URL: http://www.actnowpng.org/sites/default/files/The $\% 20$ new $\%$ 20land $\% 20$ grab $\% 20$ in $\% 20$ Papua $\% 20$ New $\% 20$ Guinea $\% 20$ Colin $\%$ 20Filer.pdf

Filer, C. 2012. The commission of inquiry into special agriculture and business leases in Papua New Guinea: fresh details for the portrait of a process of expropriation. Paper presented at the International Conference on Global Land Grabbing II, Cornell University, Ithaca, New York, USA. [online] URL: http://www. cornell-landproject.org/download/landgrab2012papers/filer.pdf

Filer, C., and N. Sekran. 1998. Loggers, donors and resource owners. Policy that works for forests and people series no. 2: Papua New Guinea. National Research Institute, Port Moresby, and International Institute for Environment and Development, London, UK.

Forest Trends. 2006. Logging, legality and livelihoods in Papua New Guinea: synthesis of official assessments of the large-scale logging industry. Volumes I and II. Forest Trends, Washington, D.C., USA.

Fox, J. C., C. K. Yosi, P. Nimiago, F. Oavika, J. N. Pokana, K. Lavong, and R. J. Keenan. 2010. Assessment of aboveground carbon in primary and selectively harvested tropical forest in Papua New Guinea. Biotropica 42(4):410-419. http://dx.doi. org/10.1111/j.1744-7429.2009.00617.x

Gardner, T. A., J. Ferreira, J. Barlow, A. C. Lees, L. Parry, I. C. G. Vieira, E. Berenguer, R. Abramovay, A. Aleixo, C. Andretti, L. E. O. C. Aragão, I. Araújo, W. S. de Ávila, R. D. Bardgett, M. Batistella, R. A. Begotti, T. Beldini, D. E. de Blas, R. F. Braga, D. de Lima Braga, J. Gomes de Brito, P. Barbosa. de Camargo, F. Campos dos Santos, V. Campos de Oliveira, A. C. N. Cordeiro, 
T. M. Cardoso, D. Reis de Carvalho, S. A. Castelani, J. C. M. Chaul, C. E. Cerri, F. de Assis Costa, C. D. Furtado da Costa, E. Coudel, A. C. Coutinho, D. Cunha, Á. D’Antona, J. Dezincourt, K. Dias-Silva, M. Durigan, J. C. D. M. Esquerdo, J. Feres, S. F. de Barros Ferraz, A. E. de Melo Ferreira, A. C. Fiorini, L. V. Flores da Silva, F. S. Frazão, R. Garrett, A. dos Santos Gomes, K. da Silva Gonçalves, J. B. Guerrero, N. Hamada, R. M. Hughes, D. C. Igliori, E. da Conceição Jesus, L. Juen, M. Junior, J. M. Barbosa de Oliveira, Jr., R. Cosme de Oliveira, Jr., C. Souza, Jr., P. Kaufmann, V. Korasaki, C. G. Leal, R. Leitão, N. Lima, M. de Fátima Lopes Almeida, R. Lourival, J. Louzada, R. MacNally, S. Marchand, M. M. Maués, F. M. S. Moreira, C. Morsello, N. Moura, J. Nessimian, S. Nunes, V. H. F. Oliveira, R. Pardini, H. C. Pereira, P. S. Pompeu, C. R. Ribas, F. Rossetti, F. A. Schmidt, R. da Silva, R. C. V. M. da Silva, T. F. M. R. da Silva, J. Silveira, J. V. Siqueira, T. S. de Carvalho, R. R. C. Solar, N. S. H. Tancredi, J. R. Thomson, P. C. Torres, F. Z. Vaz-de-Mello, R. C. S. Veiga, A. Venturieri, C. Viana, D. Weinhold, R. Zanetti, and J. Zuanon. 2013. A social and ecological assessment of tropical land uses at multiple scales: the Sustainable Amazon Network. Philosophical Transactions of the Royal Society B: Biological Sciences 368 (1619). http://dx.doi.org//10.1098/rstb.2012.0166

Gelu, A. 2010. Politics and governance. Pages 141-165 in T. Webster and L. Duncan, editors. Papua New Guinea's development performance 1975-2008. National Research Institute Monograph No. 41. National Research Institute, Boroko, Papua New Guinea.

Government of Papua New Guinea. 2007. Papua New Guinea national biodiversity strategy and action plan. Port Moresby, Papua New Guinea.

Governments of Papua New Guinea and Costa Rica. 2005. Reducing emissions from deforestation in developing countries: approaches to stimulate action. Submission by the governments of Papua New Guinea \& Costa Rica to the 11th Conference of the Parties to the UNFCCC. United Nations Framework Convention on Climate Change (UNFCCC), Montreal, Quebec, Canada.

Greenpeace. 2010. Papua New Guinea: not ready for REDD. Greenpeace Australia Pacific, Sydney, Australia.

Greenpeace. 2012. Up for grabs: millions of hectares of customary land in PNG stolen for logging. Greenpeace Australia Pacific, Sydney, Australia.

Gridneff, I. 2010. More carbon chaos in PNG. Page 13. PostCourier. 12 October.

Indrarto, G. B., P. Murharjanti, J. Khatarina, I. Pulungan, F. Ivalerina, J. Rahman, M. N. Prana, I. A. P. Resosudarmo, and E. Muharrom. 2012. The context of REDD+ in Indonesia: drivers, agents and institutions. Working Paper 92. Center for International Forestry Research (CIFOR), Bogor, Indonesia.

Ingold, K. 2011. Network structures within policy processes: coalitions, power, and brokerage in Swiss climate policy. Policy Studies Journal 39(3):435-459. http://dx.doi.org/10.1111/ j.1541-0072.2011.00416.x

Ingold, K., and F. Varone. 2012. Treating policy brokers seriously: evidence from the climate policy. Journal of Public Administration Research and Theory 22(2):319-346. http://dx.doi.org/10.1093/ jopart/mur035
International Tropical Timber Council. 2007. Achieving the ITTO objective 2000 and sustainable forest management in Papua New Guinea: report of the diagnostic mission. Forty-second session. 7-12 May 2007. Port Moresby, Papua New Guinea. [online] URL: http://www.itto.int/direct/topics/topics pdf download/ topics id $=36320000 \&$ no $=1 \&$ disp $=$ inline

Kekic, L. 2007. The Economist Intelligence Unit's index of democracy. The Economist. [online] URL: http://www.economist. com/media/pdf/DEMOCRACY INDEX 2007 v3.pdf

Knoke, D., F. U. Pappi, J. Broadbent, and Y. Tsujinaka. 1996. Comparing policy networks: labour politics in the U.S., Germany, and Japan. Cambridge University Press, Cambridge, UK. http:// dx.doi.org//10.1017/CBO9781139174497

Korhonen-Kurki, K., M. Brockhaus, A. E. Duchelle, S. Atmadja, and P. T. Pham. 2012. Multiple levels and multiple challenges for REDD+. Pages 91-110 in A. Angelsen, M. Brockhaus, W. D. Sunderlin, and L. V. Verchot, editors. Analysing REDD+: challenges and choices. Center for International Forestry Research, Bogor, Indonesia.

Kriesi, H., S. Adam, and M. Jochum. 2006. Comparative analysis of policy networks in Western Europe. Journal of European Public Policy 13:341-361. http://dx.doi.org/10.1080/13501760500528803

Kriesi, H., and M. Jegen. 2001. The Swiss energy policy elite: the actor constellation of a policy domain in transition. European Journal of Political Research 39(2):251-287. http://dx.doi. org/10.1111/1475-6765.00577

Laumann, E. O., and D. Knoke. 1987. The organizational state: social choice in national policy domains. University of Wisconsin Press, Madison, Wisconsin, USA.

Laurance, W. 2010. Better governance to save rainforests. Nature 467(7317):789. http://dx.doi.org/10.1038/467789d

Laurance, W. F., T. Kakul, R. J. Keenan, J. Sayer, S. Passingan, G. R. Clements, F. Villegas, and N. S. Sodhi. 2011. Predatory corporations, failing governance, and the fate of forests in Papua New Guinea. Conservation Letters 4(2):95-100. http://dx.doi. org/10.1111/j.1755-263X.2010.00156.X

Marsh, D., and R. A. W. Rhodes, editors. 1992. Policy networks in British government. Clarendon, Oxford, UK. http://dx.doi. org/10.1093/acprof:oso/9780198278528.001.0001

Melick, D. 2010. Credibility of REDD and experiences from Papua New Guinea. Conservation Biology 24(2):359-361. http:// dx.doi.org//10.1111/j.1523-1739.2010.01471.x

Mintrom, M., and S. Vergari. 1996. Advocacy coalitions, policy entrepreneurs, and policy change. Policy Studies Journal 24 (3):420-434. http://dx.doi.org/10.1111/j.1541-0072.1996.tb01638. $\underline{x}$

National Research Institute. 2007. Land administration, land dispute settlement, and customary land development. National Research Institute, Port Moresby, Papua New Guinea.

National Strategic Plan Taskforce. 2010. Papua New Guinea vision 2050. Independent State of Papua New Guinea, Port Moresby, Papua New Guinea.

Office of Climate Change and Development. 2011. UN collaborative programme on reducing emissions from deforestation 
and forest degradation in developing countries (UN-REDD). National programme document. Office of Climate Change and Development, Port Moresby, Papua New Guinea.

Office of Climate Change and Development. 2012. Papua New Guinea $R E D D+$ readiness preparation proposal $(R-P P)$. Office of Climate Change and Development, Port Moresby, Papua New Guinea.

Ostrom, E., and H. Nagendra. 2006. Insights on linking forests, trees, and people from the air, on the ground, and in the laboratory. Proceedings of the National Academy of Sciences of the United States of America 103(51):19224-19231. http://dx.doi.org/10.1073/ pnas.0607962103

Overseas Development Institute. 2007. What can be learnt from the past? A history of the forestry sector in Papua New Guinea. Overseas Development Institute, London, UK.

Papua New Guinea Commission of Inquiry into Aspects of the Forest Industry, T. E. Barnett, and Asia-Pacific Action Group. 1990. The Barnett report: a summary of the report of the commission of inquiry into aspects of the timber industry in Papua New Guinea. Asia-Pacific Action Group, Hobart, Tasmania, Australia.

R Core Team. 2013. R: a language and environment for statistical computing. R Foundation for Statistical Computing, Vienna, Austria.

Sabatier, P., and H. C. Jenkins-Smith. 1993. Policy change and learning: an advocacy coalition approach. Westview, Boulder, Colorado, USA.

Sabatier, P. A. 1998. The advocacy coalition framework: revisions and relevance for Europe. Journal of European Public Policy 5 (1):98-130. http://dx.doi.org//10.1080/13501768880000051

Sabatier, P. A., and C. M. Weible. 2007. The advocacy coalition framework: innovations and clarifications. Pages 189-220 in P. A. Sabatier, editor. Theories of the policy process. Second edition. Westview, Boulder, Colorado, USA.

Saunders, C. 2007. Using social network analysis to explore social movements: a relational approach. Social Movement Studies: Journal of Social, Cultural and Political Protest 6(3):227-243. http://dx.doi.org//10.1080/14742830701777769

Schmink, M. C., and C. H. Wood. 1992. Contested frontiers in Amazonia. Columbia University Press, New York, New York, USA.

Shearman, P., J. Bryan, J. Ash, P. Hunnam, B. Mackey, and B. Lokes. 2008. The state of the forests of Papua New Guinea: mapping the extent and condition of forest cover and measuring the drivers of forest change in the period 1972-2002. University of Papua New Guinea, Port Moresby, Papua New Guinea.

Shearman, P. L., J. Ash, B. Mackey, J. E. Bryan, and B. Lokes. 2009. Forest conversion and degradation in Papua New Guinea 1972-2002. Biotropica 41(3):379-390. http://dx.doi.org//10.1111/ j.1744-7429.2009.00495.x

Soares-Filho, B., P. Moutinho, D. Nepstad, A. Anderson, H. Rodrigues, R. Garcia, L. Dietzsch, F. Merry, M. Bowman, L. Hissa, R. Silvestrini, and C. Maretti. 2010. Role of Brazilian
Amazon protected areas in climate change mitigation. Proceedings of the National Academy of Sciences of the United States of America 107(24):10821-10826. http://dx.doi.org//10.1073/ pnas.0913048107

Somare, M. 2005. Statement by Sir Michael T. Somare, GCMG KSt.J CH, Prime Minister of Papua New Guinea. Presented at the Global Roundtable on Climate Change, Columbia University, New York, New York, USA. [online] URL: http://www. rainforestcoalition.org/SirMichaelSomareGROCCSpeech-FINAL. pdf

Somare, M. 2009. Parliamentary statement: carbon trading and Office of Climate Change and Environmental Sustainability. The National. 5 August.

Somare, M. 2010. Speech given by Rt. Hon. Grand Chief Sir Michael T. Somare MP GCL GCMG CH CF KStJ, Prime Minister, Papua New Guinea. Oslo Forest Climate Conference, 26 May. [online] URL: http://www.redd-monitor.org/wordpress/wpcontent/uploads/2010/06/PM-Somare-at-Oslo-Forest-ClimateConference-27-May-2010-Final.pdf

Talu, P. 2009. Carbon sale on. Page 1. The National. 12 November.

Transparency International. 2009. Global corruption report 2009: corruption and the private sector. Cambridge University Press, Cambridge, UK.

Transparency International. 2011. Global corruption report: climate change. Earthscan, London, UK.

Transparency International. 2013. Corruption perceptions index 2013. Transparency International, Berlin, Germany. [online] URL: http://cpi.transparency.org/cpi2013/results/

UN-REDD Programme. 2009. National programme document, annual and semi-annual reports. UN-REDD Programme, Geneva, Switzerland. online [URL]: http://www.un-redd.org/

AsiaPacific_NationalProgrammeDocument/tabid/106607/Default. $\underline{\text { aspx }}$

Weible, C. M. 2005. Beliefs and perceived influence in a natural resource conflict: an advocacy coalition approach to policy networks. Political Research Quarterly 58(3):461-475. http://dx. doi.org/10.1177/106591290505800308

Weible, C. M. 2006. An advocacy coalition framework approach to stakeholder analysis: understanding the political context of California marine protected area policy. Journal of Public Administration Research and Theory 17(1):95-117. http://dx.doi. org/10.1093/jopart/muj015

Weible, C. M., and P. A. Sabatier. 2005. Comparing policy networks: marine protected areas in California. Policy Studies Journal 33(2):181-201. http://dx.doi.org/10.1111/j.1541-0072.2005.00101. $\underline{\mathrm{X}}$

Weible, C. M., P. A. Sabatier, H. C. Jenkins-Smith, D. Nohrstedt, A. D. Henry, and P. deLeon. 2011. A quarter century of the advocacy coalition framework: an introduction to the special issue. Policy Studies Journal 39(3):349-360. http://dx.doi. org/10.1111/j.1541-0072.2011.00412.x

Weible, C. M., P. A. Sabatier, and K. McQueen. 2009. Themes and variations: taking stock of the advocacy coalition framework. 
Policy Studies Journal 37(1):121-140. http://dx.doi.org/10.1111/ j.1541-0072.2008.00299.x

Wickham, H. 2009. ggplot2: elegant graphics for data analysis. Springer, New York, New York, USA.

Young, O. R., E. F. Lambin, F. Alcock, H. Haberl, S. I. Karlsson, W. J. McConnell, T. Myint, C. Pahl-Wostl, C. Polsky, P. S. Ramakrishnan, H. Schroeder, M. Scouvart, and P. H. Verburg. 2006. A portfolio approach to analyzing complex humanenvironment interactions: institutions and land change. Ecology and Society 11(2): 31. [online] URL: http://www.ecologyandsociety. org/vol11/iss $2 / \operatorname{art} 31 /$

Zafonte, M., and P. Sabatier. 1998. Shared beliefs and imposed interdependencies as determinants of ally networks in overlapping subsystems. Journal of Theoretical Politics 10 (4):473-505. http://dx.doi.org/10.1177/0951692898010004005 
Appendix 1. Number of policy actors (organizations) in each actor group and their participation in the survey and interview.

\begin{tabular}{|c|c|c|c|c|c|c|}
\hline Actor group & & No. of actors & $\begin{array}{c}\text { No. of survey } \\
\text { respondents }\end{array}$ & $\begin{array}{c}\text { Survey response } \\
\text { rate }(\%)\end{array}$ & $\begin{array}{c}\text { No. of interview } \\
\text { participants }\end{array}$ & $\begin{array}{c}\text { Interview } \\
\text { coverage }(\%)\end{array}$ \\
\hline Government & & 12 & 7 & $58 \%$ & 5 & $42 \%$ \\
\hline University/Research institutes & & 8 & 6 & $75 \%$ & 4 & $50 \%$ \\
\hline Private sector & & 12 & 5 & $42 \%$ & 3 & $25 \%$ \\
\hline National NGOs & & 12 & 10 & $83 \%$ & 7 & $58 \%$ \\
\hline International NGOs & & 10 & 9 & $90 \%$ & 4 & $40 \%$ \\
\hline International organizations & & 2 & 1 & $50 \%$ & 0 & $0 \%$ \\
\hline Donor & & 10 & 7 & $70 \%$ & 5 & $50 \%$ \\
\hline & Total & 66 & 45 & $68 \%$ & 28 & $42 \%$ \\
\hline
\end{tabular}

